\section{The Edibility of Reticularia Lycoperdon (Myxomycetes) in Central Mexico}

\section{María Mercedes Rodríguez-Palma ${ }^{1}$, Adriana Montoya ${ }^{1 *}$, Ale- jandro Kong ${ }^{1}$ and Rosario Vanegas ${ }^{2}$}

${ }^{1}$ Centro de Investigación en Ciencias Biológicas, Universidad Autónoma de Tlaxcala, Mexico

${ }^{2}$ Taller de Etnobiología, Facultad de Ciencias, Universidad Nacional Autónoma de México, Mexico

\begin{abstract}
Reticularia lycoperdon is a Myxomycetes species characterized by large whitish fruiting bodies and reticulated spores. It is one of the largest Myxomycetes species. As part of an ethnomicologycal study done in San Lorenzo Tlacoyucan, Mexico City, the use of this Slime mold was recorded. New data on the edibility and preparation in central Mexico are provided. The loss of knowledge on use of this slime mold is an ongoing process. Further research is needed to better understand how these species were used in the past as food resources in different parts of Mexico, and to find information on their actual use in other countries around the world.
\end{abstract}

Keywords: Cheese mushroom; Edible Myxomycetes; Ethnomycology; moon shit; Slime molds

\section{Introduction}

Ethnomycology research has increased around the world and the topics addressed, have included edible fungi [1,2], marketing [3], and more recently the description of methods for mushroom foraging [4], among others. However, there are few reports of knowledge and use of Myxomycetes. This is a group of organisms with a complicated life cycle, because they have different phases (amebae, plasmodium, sporocarps, spores). As a consequence, they have been classified as part of animal, plant [5], fungi [6] or protist kingdoms by different authors. Presently they are classified as part of the amebozoa super-group [7].

*Corresponding author: Adriana Montoya, Centro de Investigación en Ciencias Biológicas, Universidad Autónoma de Tlaxcala, Mexico, Tel: +52 2484815482 Email: ametnomicol@hotmail.com

Citation: Rodríguez-Palma MM, Montoya A, Kong A, Vanegas R (2017) The Edibility of Reticularia lycoperdon (Myxomycetes) in Central Mexico. J Food Sci Nut 3: 025.

Received: August 23, 2017; Accepted: October 05, 2017; Published: October 19, 2017
Myxomycete comprises a relatively small and homogeneous group of amoeboid eukaryotic organisms, which lack a cell wall. They are abundant in forests and agricultural soils, play an essential role in the ecosystem and food chain by feeding on bacteria and other microorganisms that are harmful to plants. Slime molds are important because, as the same as fungi, accumulate high metals in their cells [8]. They also provide food and dwelling for numerous mites and insects, mainly Coleoptera (beetles) and Diptera (flies). While most of the Myxomycete species are relatively small in size (a few millimeters), some are large enough to have been reported in Mexico and Ecuador to be edible [9-13].

Only fragmentary information has been available primarily from the states of Veracruz, Tlaxcala, and Michoacan, Central Mexico. Therefore, as part of an ethnomicologycal research in the town San Lorenzo Tlacoyucan, Mexico City, we recorded the use of a slime mold Reticularia lycoperdon Bull. It is important to investigate the nomenclature and edibility of this Myxomycetes in different regions in Mexico for various indigenous groups because it represents a traditional food; culturally it looks to have been very significant in the past, more than today. The present study aims to show the use and knowledge of $R$. lycoperdon in parts of Mexico mainly in states located in the neovolcanic axis.

\section{Material and Methods}

\section{Study area}

Milpa Alta Municipality, Tlaxcala and Michoacan are within the physiographic province of the Trans-Mexican Volcanic Belt [14], (Figure 1). The climate on these study sites is temperate sub-humid with mostly summer rains (700-1600mm rainfall). June, July and August are the wettest months. In the highest peaks of the mountains, the weather is semi-cold to cold. According to Rivera-Hernández \& Espinosa-Henze [15], there are five types of vegetation in the Milpa Alta, forest fir (Abies religiosa), pine (Pinus spp, forest of oak (Quercus spp.), grassland, and desert scrub. The residents from San Lorenzo Tlacoyucan $(3796 \mathrm{~m})$ in Milpa Alta, are primarily Nahuas in ancestry. The people mainly engage in housework and fieldwork. One of the main activities is the cultivation of nopal (Opuntia spp.), raising sheep and pigs, and collecting forest products including 37 species of wild mushrooms (for example: Amanita basii Guzmán \& Ram.Guill. [polonco, jícara], Lyophyllum decastes (Fr.) Singer [clavitos = little nail], Boletus pinophilus Pilát $\&$ Dermek [pancitas $=$ little belly] Ramaria spp. [escobetas = brooms], Cantharellus aff. cibarius Fr. [duraznillo $=$ little peach] for household consumption and sale.

In the Malinche National Park in Tlaxcala, the dominant vegetation in the highlands is temperate forest (with a predominance of fir, pine, alder, and mixtures of them) and oak forest in the foothills. Mestizo people from Mariano Matamoros and Nahua descent from San Isidro Buensuceso reside around the Malinche National Park in Tlaxcala. San Miguel Canoa belongs to the state of Puebla, where the population is mainly of Nahua descent and they engages in field work and different forest activities like collecting wild mushrooms. 


\section{A}
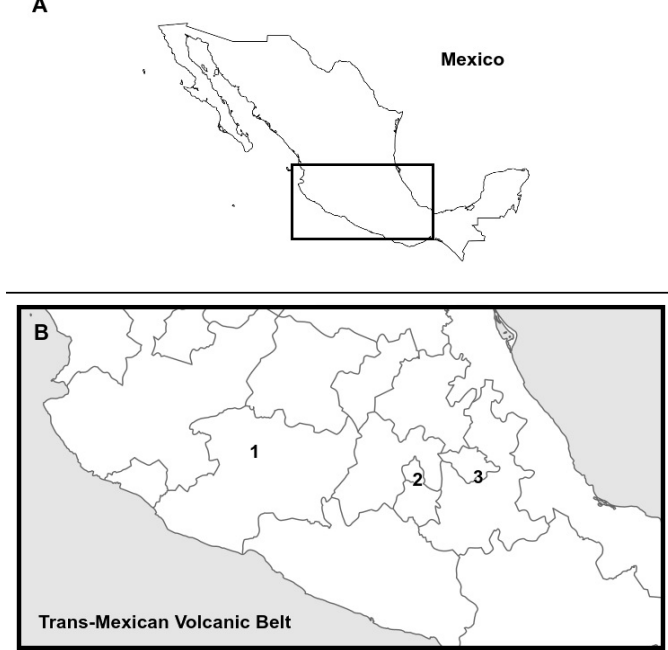

Figure 1: Map showing the areas from Mexico, where edibility information about the Myxomycetes Reticularia lycoperdon has been registered. a) Mexico with the study area in a frame. b) Tran-Mexican Volcanic Belt area, 1) Cherán, Michoacán, 2) San Lorenzo Tlacoyucan, Milpa Alta, Ciudad de México, 3) La Malinche National Park.

\section{Ethnomycological information}

In the present study, as part of an ethnomycological survey conducted in San Lorenzo Tlacoyucan, Milpa Alta, very specific and detailed information about the species of Myxomycetes was obtained. Looking for other sites where the uses of the species were similar, five interviews were conducted with mushroom collectors in the forests of La Malinche Volcano, in Tlaxcala and Puebla. Moreover, information from Cheran community, in Michoacan, was included. Myxomycetes were searched and collected in the company of hongueros ("mushroomers" local experts, known as such, by almost all people in their village). The trips were made in to the forests of each place where $R$. lycoperdon was known. The collecting sites and dates as well as the process of preparation of collected Myxomycetes for consumption were also documented.

A total of 115 semi-structured ethnomycological interviews with residents in San Lorenzo Tlacoyucan were conducted [16] to document the mushroom traditional knowledge. In these interviews, only one person mentioned detailed information about $R$. lycoperdon. With the intention of learning in which other areas from central Mexico this slime mold is used, visits were made to the forests of La Malinche, to interview mushroom pickers and have knowledge and information about possible use of $R$. lycoperdon. Through participant observation, and interviews (asking questions about names, places and time for growing, recipes for cooking, ways to collect and transport) trips to the forests were conducted every two weeks during the rainy season of 2015 to document the way to collect and cook this slime mold. The information obtained was supplemented with literature records, including information published for Ecuador. Interviews were made with five local residents who are experts on searching mushrooms and Myxomycetes.

As a special case, additional information on the edibility of $R$. $l y$ coperdon was obtained in Cheran, Municipality of Cheran, Michoacan, through a comprehensive interview. This information was provided by Mrs. Adelaida Cocué Rivera, a native resident of the town, who collected edible Myxomycetes in coniferous forests (mainly pine) in this area.

\section{Taxonomic identification}

The collected samples of Myxomycetes were examined under stereo, light microscopy, and Nomarski interference contrast microscopy, after fixing with the Hoyer's solution. Similarly, the keys and specific descriptions published by Martin \& Alexopoulos [5], Nannenga-Bremekamp [17] and Poulain et al., [18] were used for taxonomic identification of Myxomycetes. All materials collected in different regions were dehydrated, identified, labeled, and deposited in the Herbarium TLXM of the Universidad Autónoma de Tlaxcala.

\section{Results}

Taxonomic description: $R$. lycoperdon is characterized by solitary Aethalia pulvinate (reproductive structures), of $15-300 \mathrm{~mm}$ in length and $10-150 \mathrm{~mm}$ in diameter, yellow or silver of irregular shape when young, later brown from the spore mass. Hypothallus often not clear. Cortex thin or thick, smooth and shiny Pseudocapillitia form very fine strips that dichotomously branch from a wide and membranous base. Spores deep brown in mass (Chart Munsell code: HUE7.5 YR $4 / 6$ ), yellow by transmitted light, banded-reticulated over about $1 / 3$ to $1 / 2$ of the total area, the surface of spores has no ornamentation, are smooth with some warts isolated or aggregated to form small rows, globose, $9.0-9.5 \mu \mathrm{m}$ in diameter without ornamentation or $10.5 \mu \mathrm{m}$ with ornamentation (Figure 2).
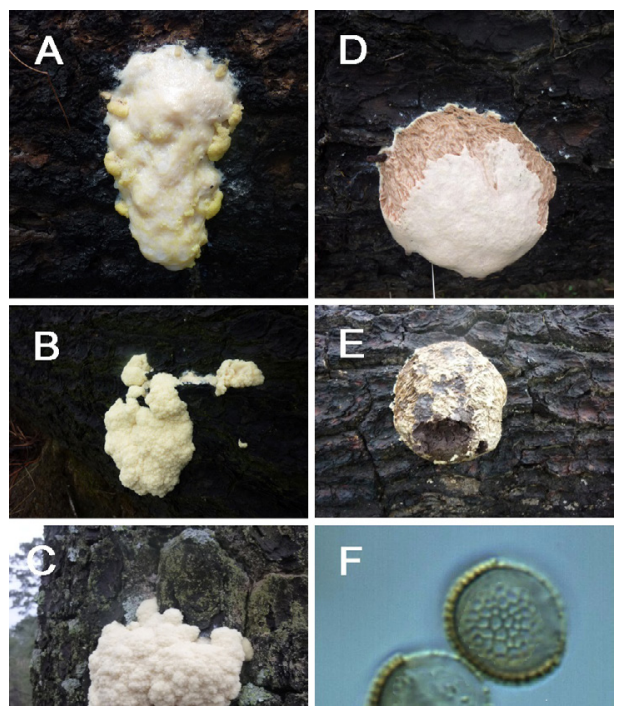

Figure 2: Fruiting bodies and spores of $R$. lycoperdon. a-d) Different stages of mature fruiting bodies of $R$. lycoperdon, e) Fruiting bodies at the fully mature stage, f) Spores with banded reticulate ornamentation.

\section{Revised Material}

México, Tlaxcala. Municipality of Huamantla, Volcán La Malinche. Abies-Pinus Forest. Estrada-Torres 3122. Rodríguez-Palma 151. Montoya-Esquivel 1399a. Mexico, Ciudad De México. Municipality of Milpa Alta, Bosque de Pinus. Vanegas-Enríquez Rosario 170512-MA75.

\section{Habitat and growing season}

In San Lorenzo Tlacoyucan, Milpa Alta, R. lycoperdon primarily grows in the pine forest on fallen logs, stumps, and bark of living trees of Pinus, which is usually 1.5 and $2.0 \mathrm{~m}$ in height. The reproductive structure begins to appear in March, increasing in April, and these, 
are sporadically found until May. In La Malinche volcano, the species grows on stumps and fallen logs of Pinus. However, it has not been found to grow on living trees, as observed in the town of San Lorenzo. Unlike in San Lorenzo Tlacoyucan, $R$. lycoperdon prefers to grow in the rainy season from July to September in La Malinche volcano.

\section{Ethnomycological information}

In San Lorenzo Tlacoyucan, $R$. lycoperdon is recognized as "cheese mushroom" because of its taste and consistency after being cooked. It has been used as food by residents in the town for many years, it is considered an ancestral tradition inherited from experts in collecting mushrooms, and they know that it grows on the fallen trunks or living trees or logs in the forest of pitch pine (Pinus).

\section{Food usage}

For consumption of $R$. lycoperdon, the residents in San Lorenzo Tlacoyucan usually pick up full fruiting bodies (reproductive structures) from the substrate with a razor or knife. On a leaf of maize (Zea mays L.) or aluminium, the fruiting bodies are mixed with salt and "epazote" leaves (Chenopodium ambrosioides L.), and wrapped to make a small packet, which is heated in hot campfire or bonfire ashes on the ground. The cooking time in hot ashes ranges between 20 and 40 minutes. After cooking, the fruiting bodies of $R$. lycoperdon changes to be viscous with elastic consistency, which is very similar to a type of cheese consumed in Mexico, called the "hebra" or "oaxaca". The taste is like almonds and mushroom (Figures 3 and 4). People usually consume the cooked Myxomycetes with corn tortillas or eat it alone. The residents from this community recommend direct consumption, on the site where it is cooked, because transport may change the consistency of cooked $R$. lycoperdon. During transport, the cooked material can undergo a liquefaction process. In this case, the immature state of fruiting bodies reverts to plasmodium condition and is not attractive for consumption.
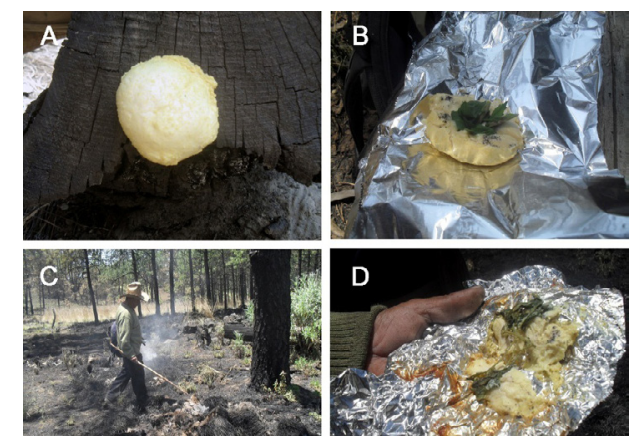

Figure 3: Collection and preparation of $R$. lycoperdon or "cheese mushroom" a) Immature state used for food preparation, b) Mixed with salt and epazote leaves on a foil, c) The fruiting bodies of the species are wrapped in an aluminum foil and heated in hot ashes, d) Cooked Myxomycetes, ready for consumption.

Residents in the communities surrounding La Malinche National Park in Tlaxcala and Puebla, Mexico also consume R. lycoperdon, which is called "moon shit", as in the region of Cofre de Perote, Veracruz [13]. However, unlike in Milpa Alta, the residents of the area bring collected Myxomycete home to cook. They recommend carring collected fruiting bodies in plastic bags to prevent the Myxomycete from drying or descomposing. They note that, "aunque se hagan agua, al cocinarlo adquiere la consistencia adecuada para comer" (although they go through a liquefaction process, when cooked has acquired a good consistency to eat). In Mariano Matamoros, municipality of Huamantla, Tlaxcala $R$. lycoperdon is known by the name "ocote egg", which is also carried in plastic bags. The residents cook the fruiting bodies by boiling it, and then washing them with cold water. The cooked organism is sliced with a knife and eaten with tortillas. According to Don Gumaro Pérez-Luna and Don Martin Perez-Luna, $R$. lycoperdon has a "requeson" taste (a kind of cheese consumed in México), and is a very delicious and special meal. It has been documented that it grows on the stumps of Pine trees or living trees in forests of Pinus hartwegii, P. montezumae, and Abies religiosa from La Malinche National Park (Figure 5).

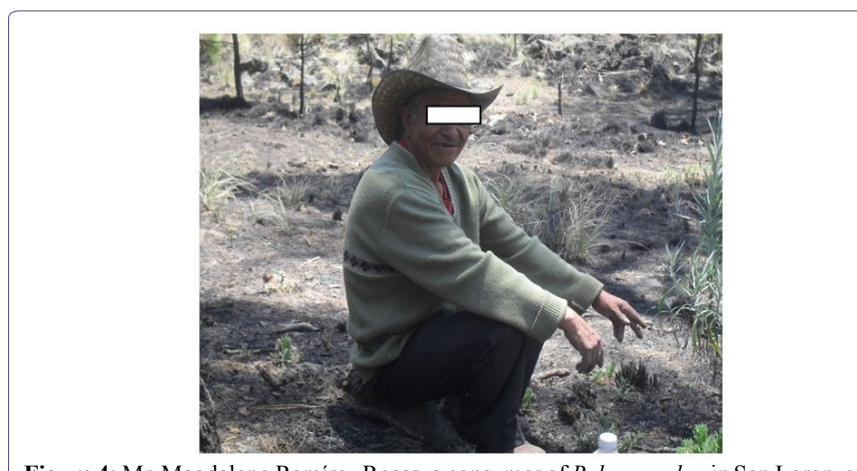

Figure 4: Mr Magdaleno Ramírez Rosas, a consumer of $R$. lycoperdon in San Lorenzo Tlacoyucan, Milpa Alta, Mexico City.

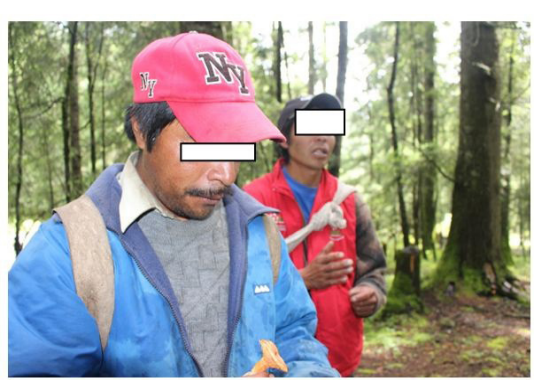

Figure 5: Interviewed residents Don Gumaro Perez-Luna (Front) and Don Martín Pérez-Luna (Back) who are $R$. lycoperdon consumers in Mariano Matamoros, La Malinche volcano in Tlaxcala, Mexico.

The residents in the community of Canoa, Puebla call R. lycoperdon as koahtotoltetl $(\mathrm{koah}=$ logs; tohtol = small female turkey; tetl = stone) that means "the egg of wood (dead logs)". It grows on large but dead trees, or stumps that can be fir, oak and pitch pine. In fresh state it is like a white jelly. To prepare it as food, it is scraped from a tree, and placed on leaves of an edible broadleaf tree, with "epazote". After it is put in a corn leaf, like a "mexican tamal" (to make a wrap) it is baked in hot coals or ashes. After cooked, the material has similar characteristics, and consistency like dough, and is eaten with tortillas. In San Isidro Buensuceso, R. lycoperdon is recognized but not used as food by the residents. In this region, this Myxomycetes species has been named as Iyekakuitlinocotl that means "wood mucus or star excrement".

In addition, $R$. lycoperdon is also consumed in some places in the state of Michoacan, and in the community of Cheran where it is recognized as a fungus, kuatsitashi, according to the documentation provided by Mrs. Adelaida Cocué. In the coniferous forests of this region, it grows on rotten wood, and is collected mainly when the moon is full or one day earlier or later. Furthermore, it has been documented 
that $R$. lycoperdon cannot be transported in iron containers that affects the consistency, color and taste. Doña Adelaida said that kuatsitashi is prepared in boiled water to make a broth. The cooked $R$. lycoperdon is like jelly, more or less hard, or like brain. Mint and green chile can be added to the cooked meal to improve its flavor.

\section{Discussion}

Mapes et al., [11] who reported Fuligo septica (L.) FH Wigg in the municipality of Erongarícuaro, Michoacán, located in Western Mexico, provided the first documentation on the edibility of Myxomycota worldwide. According to the authors, the Myxomycete is considered as a fungus and the local residents classified it into "Tamanda", a group of fungi that grow on logs (according to the mushroom traditional classification of Purepecha ethnic group). Specifically, they referred F. septica (other Myxomycetes species) as "Tamanda kuatsita", which means "indicative fungus" or "good fungus" and local residents consume it like eggs.

The same species, F. septica, was also reported to be edible in Ixtenco and Los Pilares, surroundings the La Malinche volcano in the state of Tlaxcala, in Central Mexico [10,12]. In these two reports, F. septica is consumed and usually combined with fried eggs, in the raw state. The local residents name it as "stick mushroom" because it usually grows on tree stumps and decaying woods.

Villarreal [13] reported another edible Myxomycetes species, E. lycoperdon (R. lycoperdon) in Cofre de Perote, Veracruz, Eastern Mexico. According to this report, some people consume it fried. They call it "moon shit", due to its round shape, soft consistency, and color. Guzmán \& Villarreal [19] also reported that F. septica and E. lycoperdon are edible, and the latter known as "moon mushroom", and is consumed in Cofre de Perote, Veracruz.

Recently, Gamboa-Trujillo et al., [9] reported that the fruiting bodies of other Myxomycetes: Lycogala epidendrum (J.C. Buxb. Ex L.) Fr. are edible and used as medicine in some regions in Ecuador. The Shuar community and "Muyo ala" by the Kichwa community know this species as "Yakich". In both Shuar and Kichwa, it is consumed as a snack of sweet taste that occurs when it is unripe. People in these regions for improving wound healing also use the spores.

While Myxomycetes have relatively small reproductive structures (mostly 1-3mm), some species, such as $R$. lycoperdon and $F$. septica, form large fruiting bodies $(>50 \mathrm{~cm}$ when immature). These species have greater biomass, which can be found easily by mushroom pickers in the forests, and included as foods. Other species such as L. epidendrum also have an aethalium, which can grow up to $2-3 \mathrm{~cm}$, usually form large colonies, and for this reason, they are useful food resources in some regions of Ecuador [9].

Less than $10 \%$ of the population uses or know about their properties. In the harvest period only two species in Mexico and one in Ecuador are known to be eaten. According with information in the literature and own observations, all members of the family consume these slime molds without any restriction related to age or pregnancy, and never had been registered any symptoms like nausea, toxicity or hallucinogenicity.

It is likely that other species of Myxomycetes, with large reproductive structures, are also edible. However, further exploration is needed to have a better understanding how these species are used as food resources in Mexico and other countries. The present study is of interest because Myxomycetes are not only consumed as food but are used as a kind of medicine in Mexico and Ecuador. This information is important because these organisms represent nutritional alternatives, which are traditional food, especially in regions with scarce resources. From a cultural point of view, the uses of this taxonomic group as food and medicine shows the knowledge of local residents on different forests resources, and the preservation of traditional knowledge of their ancestors. Frequent contact with the forest allows multiple usages of non-timber resources by people. However, traditional information on the food usage of these Myxomycetes species is usually not accessible to the general or young population. It has been observed that interviewed people, are experts on the collection and use of Myxomycetes as food. They are mostly dedicated to frequent collection of mushrooms during the rainy season. These specialists come to the forest frequently also during the dry season each year. On wood or wild plants, they observe the growth and morphology of Myxomycetes. For example, the residents in San Lorenzo Tlacoyucan collected mushrooms between January and March. The information documented by local mushroom pickers is important to know the appropriate time for the formation of reproductive structures. It has been reported that the growth of $R$. lycoperdon in La Malinche and Michoacan is mainly in the rainy season (from August to September). Traditional knowledge of this Myxomycete is getting lost through disuse and with the passing of the mushroom experts. In the areas where the traditional experts live, several social changes are occurring (migration, formal education access, change in economic activities) and specific knowledge about resources is not passing on to new generations; this is the case of $R$. lycoperdon.

In the harvest period, the expert mushroom collectors are the people who know the places, time and manner of use (less than $10 \%$ of the people). For this reason at the moment, this organisms are considered as a delicacy, instead a source of food during the harvest period. We consider it is important to do a specific research to determine the current traditional knowledge and the importance of these organisms to different cultures in the world. This organisms represent a good potential for metabolites [20], for this reason, it is neccesary to investigate about their nutritional value, and examine the compounds in these.

In Mexico, slightly over 323 Myxomycetes species have been identified, which account for a third of the known species worldwide (Lado \& Wrigley de Basanta [21]). One hundred and sixty-one species and three varieties have been reported in Tlaxcala [22]. La Malinche National Park, located in the southern region of the Tlaxcala state, has a high diversity of these organisms. In Mexico City, only 13 species of this group including $R$. lycoperdon have been reported [23]. However, there are still many regions in which, the Myxobiota have not been documented and investigated. For this reason, there is still no accurate information on the particular ecological requirements of these species. It has been documented that forest fragmentation and the reduction of fallen timber are major factors limiting the availability of substrates for the development of Myxomycetes, including the edibles. The growth of many species at various states depends on the degradation of logs, stumps, branches, and leaves to complete their life cycle. Therefore, forest management plays a key role in the development of these organisms. Similarly, little had been studied about the use of these as food alternatives. This scenario provides a vast potential for understanding the cultural importance of these edible groups. 


\section{Acknowledgement}

The authors acknowledge funding of Project PRODEP, UATLX-CA-229. We especially thank Mrs. Adelaida Cocué from Cheran in Michoacán, to Nicolás Pérez, Pérez from Canoa, Puebla, to Francisco Flores from San Isidro Buensuceso, Don Gumaro Pérez-Luna and Don Martin Perez-Luna in Mariano Matamoros, Tlaxcala. Particularly to Mr. Magdaleno Ramírez Rosas from San Lorenzo Tlacoyucan, Milpa Alta for their hospitality, sharing their knowledge and experience on edible Myxomycetes, and accepting the decision and photo exhibition to this paper. Also we would like to acknowledge the time and efforts to the anonymous reviewers to improve the first version of our manuscript and the English language suggestions.

\section{Author's contribution}

$\mathrm{AM}$ and RV conceived and designed the original research about Ethnomycology. All authors collected data and collaborate in the field trips to different areas looking for R. lycoperdon and doing interviews. MMRP wrote the first version of the paper and confirm the species. All authors reviewed the manuscript and approved the final version.

\section{References}

1. Boa E (2005) Los hongos silvestres comestibles: perspectiva global de su uso e importancia para la población. Food and Agriculture Organization of the United Nations (FAO), Rome, Italy.

2. Yamin-Pasternak S (2008) From Disgust to Desire: Changing Attitudes toward Beringian Mushrooms. Economic Botany 62: 214-222.

3. Montoya A, Hernández N, Mapes C, Kong A, Estrada-Torres A (2008) The collection and sale of wild mushrooms in a community of Tlaxcala, Mexico. Economic Botany 62: 413.

4. Pacheco-Cobos L, Roseti M, Quatianquiz C, Hudson R (2010) Sex differences in mushrooms gathering: men expend more energy to obtain equivalent benefits. Evolution and Human Behavior 31: 289-297.

5. Martin GW, Alexopoulos CJ (1969) The Myxomycetes. Academic Press, Cambridge, Massachusetts, USA.

6. Alexopoulos CJ, Mims CW (1979) Introductory Mycology, ( $3^{\text {rd }}$ edn). John Wiley \& Sons Inc, Dunfermline, UK.

7. Baldauf SL (2008) An overview of the phylogeny and diversity of eukaryotes. Journal of Systematics and Evolution 46: 263-273.

8. Setälä A, P Nuorteva (1989) High metal contents found in Fuligo septica 1. Wiggers and some other slime moulds Myxomycetes. Karstenia 29: 37-44.

9. Gamboa-Trujillo P, Grefa G, Uwinjin P, Piyaguaje D, Cavalcanti LH (2011) Myxomycetes of Ecuador: Ethnomycological notes. Abstracts of the VII International Congress on Systematic and Ecology of Myxomycetes Recife, Brasil.
10. González FI (1987) Los hongos del estado de Tlaxcala. Contribución al conocimiento de la micoflora regional. Tesis de Licenciatura. Tlalnepantla, Estado de México: Escuela Nacional de Estudios Profesionales Iztacala, Universidad Nacional Autónoma de México.

11. Mapes C, Guzmán G, Caballero J (1981) Etnomicología purépecha. El conocimiento y uso de los hongos en la cuenca de Pátzcuaro, Michoacán. Cuadernos de Etnobiología 2. Distrito Federal: Dirección General de Culturas Populares, Sociedad Mexicana de Micología, Universidad Nacional Autónoma de México.

12. Montoya A, Estrada-Torres A, Caballero J (2002) Comparative ethnomycological survey of three localities from La Malinche Volcano, Mexico. Journal of Ethnobiology 22: 103-131.

13. Villarreal L (1983) Algunas especies de Myxomycetes no registradas del estado de Veracruz. Boletín de la Sociedad Mexicana de Micología 18: 153-164.

14. INEGI (2009) Prontuario de información geográfica delegacional de los Estados Unidos Mexicanos. Milpa Alta, Distrito Federal, México.

15. Rivera-Hernández JE, Espinosa-Henze A (2007) Flora y vegetación del Distrito Federal. In: Vega IL, Morrone JJ, Espinosa D (eds.), Biodiversidad de la Faja Volcánica Transmexicana. Ciudad de México: Universidad Nacional Autónoma de Mexico, Mexico, USA.

16. Alexiades MN (1996) Collecting Ethnobotanical Data: An Introduction to Basic Concepts and Techniques. In: Alexiades MN (ed.). Selected Guidelines for Ethnobotanical Research: A Field Manual. New York Botanical Garden, New York, USA.

17. Nannenga-Bremekamp N (1991) A guide to temperate Myxomycetes. Biopress.

18. Poulain M, Meyer M, Bozonnet J (2011) Les Myxomycétes. France: Fédération mycologique et botanique Dauphiné-Savoie.

19. Guzmán G, Villarreal L (1984) Estudio sobre los hongos, líquenes y mixomicetos del Cofre de Perote, Veracruz I. Introducción a la micoflora de la región. Boletín de la Sociedad Mexicana de Micología 19: 107-124.

20. Keller HW, Sydney E (2010) Importance of Myxomycetes in Biological Research and Teaching. Papers in Plant Pathology 366.

21. Lado C, Wrigley De Basanta DA (2008) Review of neotropical Myxomycetes (1828-2008). Anales del Jardín Botánico de Madrid 65: 211-254.

22. Rodríguez-Palma M, Estrada-Torres A, Hernández-Cuevas L (2005) Myxomycetes. In: Fernández JA, López-Domínguez JC (eds.). Biodiversidad del Parque Nacional Malinche. Tlaxcala: Coordinación General de Ecología and Gobierno del Estado de Tlaxcala, Tlaxcala, Mexico.

23. Moreno G, Lizárraga M, Illana C (2007) Catálogo de los Myxomycetes de México. Boletín de la Sociedad Micológica de Madrid 31: 187-229. 